\title{
Loss of heterozygosity in the short arm of human chromosome 3 in sporadic lung cancer*
}

\author{
Lina Marcela Barrera, Biol ${ }^{1 * *}$, Lizeth Marelly Álvarez, Biol. ${ }^{1^{* *}}$, \\ Miguel Ignacio Roldán, MD², Héctor Ortega, MD³ ${ }^{3}$ Omar Triana, PhD4, \\ Alonso Martínez, $P_{H} D^{5}$
}

\section{SUMMARY}

Introduction: Loss of Heterozygocity ( $\mathrm{LOH})$ in the short arm of human chromosome $3(3 p)$ is a frequent event in different types of sporadic tumors, including lung cancer (LC).

Aim: To determine 3p LOH in LC samples using 17 microsatellite markers.

Methodology: In a pilot study on volunteers, thirteen LC biopsies (tumor tissue) and $4 \mathrm{ml}$ of blood (normal tissue) from the same patient were collected. DNA extraction and Polymerase Chain Reaction (PCR) were performed with 17 microsatellite markers to analyze LOH. Amplified fragments were run on $6 \%$ denaturalizing polyacrilamide gels and were visualized by using silver stain. Descriptive analysis was performed for each region on the $3 p$ chromosome.

Results: All tumors were informative for one or more of the analyzed markers. LOH was found in one or more loci in eleven samples (84.6\%). The markers with major LOH were UBE1L (23.1\%), D3S1317, D3S1300, D3S1284, D3S1274, D3S3049, and D3S1577 (15.4\%). Three samples showed microsatellite instability (changes in the length of the microsatellite) in different loci. The percentages of LOH for the regions of $3 p$ were: $17.6 \%$ for $3 \mathrm{p} 24-25,11.62 \%$ for $3 \mathrm{p} 21-22$, $20 \%$ for $3 \mathrm{p} 13$ 14 , and $18.42 \%$ for the $3 \mathrm{p} 12$ region.

Conclusions: Chromosomal regions with allelic loss were identified where probably other GSTs involved in the development of the LC are localized. It should increases sample size and marker number in order to narrow a minimal region and to identify a unknown gene involved in LC.

Colomb Med. 2010; 41: 358-66

Keywords: Lung cancer; Microsatellite markers; Loss of heterozygosity (LOH).

Pérdida de heterocigocidad en el brazo corto del cromosoma 3 humano en cáncer esporádico de pulmón

\section{RESUMEN}

Introducción: La pérdida de heterocigocidad ( $\mathrm{LOH}$ ) en el brazo corto del cromosoma 3 (3p) humano es un evento frecuente en diferentes tipos de tumores esporádicos, incluyendo cáncer de pulmón (CP).

Objetivo: Determinar la LOH de 3p en muestras de CP, con 17 marcadores microsatelitales.

Metodología: En un estudio piloto en voluntarios, se recolectaron 13 biopsias de CP (tejido tumoral) y $4 \mathrm{ml}$ de sangre periférica (tejido normal) del mismo paciente, se extrajo el ADN y se realizaron reacciones en cadena de la polimerasa (PCR)

* This project was funded by the Committee for the Research Development (CODI in Spanish). Initiation Acts: CPT 8840414 and CPT 8840-415.

** When this project was begun, LMB y LMA belonged to Infection and Cancer Group.

1. Associate researcher Bacteria \& Cancer Group, Department of Microbiology and Parasitology, School of Medicine, Universidad de Antioquia, Medellín, Colombia. e-mail: linabarrera07@yahoo.com lizethalvarezsalas@yahoo.com

2. Professor, Department of Pathology, School of Medicine, Universidad de Antioquia, Medellín, Colombia. e-mail: mirope65@yahoo.com

3. Professor, Pneumology Section, Department of Internal Medicine, School of Medicine, Universidad de Antioquia, Medellín, Colombia. e-mail: hortega@une.net.co

4. Leader Chagas Group, Professor Institute of Biology, Faculty of Exact and Natural Sciences, Universidad de Antioquia, Medellín, Colombia. e-mail: otriana@gmail.com

5. Leader Bacteria \& Cancer Group, Assistant Professor, Department of Microbiology and Parasitology, School of Medicine, Universidad de Antioquia, Medellín, Colombia. e-mail: amartine@une.net.co Received for publication September 8, 2009 Accepted for publication May 7, 2010 
con 17 marcadores microsatelitales para analizar LOH. Los fragmentos amplificados se corrieron en geles de poliacrilamida desnaturalizante al $6 \%$ y se visualizaron por medio de la coloración de tinción de plata. El análisis descriptivo se realizó para cada región estudiada en el cromosoma $3 p$.

Resultados: Todos los tumores fueron informativos para uno o más de los marcadores analizados. Se encontró LOH en uno o más loci en 11 muestras $(84.6 \%)$. Los marcadores con mayores $\mathrm{LOH}$ fueron UBE1L (23.1\%), D3S1317, D3S1300, D3S1284, D3S1274, D3S3049 y D3S1577 con 15.4\%. Tres muestras presentaron inestabilidad microsatelital (cambios en la longitud del microsatélite) en diferentes loci. Los porcentajes de $\mathrm{LOH}$ para las regiones de $3 \mathrm{p}$ fueron: $17.6 \%$ para $3 \mathrm{p} 24-25,11.6 \%$ para $3 \mathrm{p} 21-22,20 \%$ para $3 \mathrm{p} 13-14$ y $18.4 \%$ para la región $3 \mathrm{p} 12$.

Conclusiones: Se identificaron regiones cromosómicas con pérdida alélica donde es probable que se localicen otros GST involucrados en el desarrollo de $\mathrm{CP}$, diferentes de los ya identificados como $V H L$, RASSF 1A, FHIT D DUTTI, entre otros. Se debe aumentar el número de muestras y de marcadores para delimitar una región mínima e identificar algún gen no descrito implicado en la carcinogénesis de pulmón.

\section{Colomb Med. 2010; 41: 358-66}

Palabras clave: Neoplasia pulmonar (NP); Marcadores microsatelitales; Pérdida de heterocigocidad (LOH).

Lung cancer (LC) represents $12.6 \%(1 ' 448,000)$ of new cancer cases in the world; it is the most frequent cause of mortality due to cancer in males $(848,132$ per year) and the second in females $(330,786 \text { per year })^{1}$. In Colombia nearly 3868 cases/year are diagnosed in a proportion of two men for one woman and there are approximately 3895 deaths per year, which places it as the third cause of deaths due to cancer ${ }^{2}$. LC originates in the respiratory epithelium and it is classified as Small-Cell Lung Cancer (SCLC) and Non-Small-Cell Lung Cancer (NSCLC). Cigarette smoking is the main risk factor causing $\mathrm{LC}$ and it is involved in up to $71 \%$ of deaths due to LC in Western countries ${ }^{3}$. In addition to tobacco, there are other factors involved in the development of LC related to life style and occupational risk factors that imply being in contact with carcinogens ${ }^{4}$.

Tumor Suppressor Genes (TSG) are implied in carcinogenesis, like also proto-oncogene and DNA repair genes; the existence of TSG is suspected when observing frequent loss of specific regions in a specific chromosome. If we correlate absence of locus with tumor development, it can be supposed that its presence avoids tumorigenesis. For a cell to acquire tumor phenotype, loss of TSG function is required, which may or may not be accompanied by over expression of protooncogene and there is also accumulation of additional mutations in other genes ${ }^{5,6}$.

Karyotypes and analysis of Loss of Heterozygosity $(\mathrm{LOH})$ are routine procedures to detect DNA deletion and serve as TSG location indicators. Several authors postulating $\mathrm{LOH}$ occurs because there is loss of the whole chromosome due to inappropriate chromosome segregation during mitosis or that it is also produced because genetic alterations change chromosome structures. Other authors suggesting mitotic recombination and gene conversion are additional mechanisms causing $\mathrm{LOH}^{7}$. Detecting genetic changes in lung epithelium is important in order to identify patients at high risk of developing LC. Pre-neoplastic and preinvasive lesions possess changes like LOH in $3 p, 9 p$, $8 \mathrm{p}$, and $17 \mathrm{p}$ arms and mutations in some oncogenes and TSG. Recent studies suggest that these changes are also observed in bronchial epithelium of normal appearance in smokers and former smokers and are even detected in sputum samples obtained from these patients, which serve as molecular biomarkers for early detection of $\mathrm{LC}^{8}$. The aim of this study is to determine $\mathrm{LOH}$ in human chromosome $3 p$ in 13 samples of sporadic LC using 17 microsatellite markers.

\section{METHODOLOGY}

This pilot study was carried out with 13 volunteer patients diagnosed with sporadic LC, without chemotherapy and/or radiotherapy treatment from whom we obtained an informed signed consent previously approved by the respective ethics committees. Through a structured interview, we obtained information on their individual life styles, including cigarette and alcohol consumption. $4 \mathrm{ml}$ of peripheral blood was obtained from each patient (normal control), together with a biopsy of the tumor, which was classified according to the American Joint Committee on Cancer (AJCC). 10 mg of tumor tissue were separated and homogenized with Proteinase K (Sigma, USA), and lymphocytes were isolated from peripheral blood through a centrifuge 
Table 1

Characteristics of $3 p$ microsatellite markers

\begin{tabular}{|c|c|c|c|c|c|}
\hline $\begin{array}{l}\text { Primer } \\
\text { name }\end{array}$ & Forward sequence (5'-3') & Reverse sequence (5'-3') & $\begin{array}{c}\mathrm{T} \\
\left({ }^{\circ} \mathrm{C}\right)\end{array}$ & $\begin{array}{c}\text { Size } \\
\text { amplified } \\
\text { (bp) }\end{array}$ & $\begin{array}{c}\text { Distance } \\
\text { in } \mathrm{CM}^{*}\end{array}$ \\
\hline D3S1304 & TTCGCTCTTTGATAGGC & ATTTCATTTGTAATTTACTAGCAG & 50 & $250-270$ & 19.61 \\
\hline D3S1537 & CTATAAAATGGCTATACCCAG & CTATTTTTGGACCCAGTAACC & 55 & 212 & 23.18 \\
\hline D3S1317 & TACAAGTTCAGTGGAGAACC & CCTCCAGGCCATACACAGTCA & 58 & 160 & 27.68 \\
\hline UBE1 & GGAGCCAGCTCAGAGCATAG & CCAGTGCAAACAGGAACCAAG & 58 & $108-117$ & 67.94 \\
\hline D3S2407 & TGTACCCTATAGAAGTAAGACCAGG & GGAGTTCAAGGTTACAGTCAGC & 55 & 214 & 67.94 \\
\hline CAP1 & TAGATGAGGAAACTGAGGCC & GGCATAACAGCCATTTGGCA & 60 & 170 & 70.89 \\
\hline D3S1568 & CCATGAACAGAACCTCCCTA & CCGCTGTCCTGCTGTAAG & 58 & 280 & 70.89 \\
\hline D3S1621 & CCAAGGAAGGGTTTTACTTA & ССTCACTACTCCTGGAATTG & 55 & 140 & 70.89 \\
\hline D3S1289 & AAAGCAACTTGTAAGAGAGCA & CTCCTAGATATAATCACTGGCA & 55 & $197-215$ & 73.73 \\
\hline D3S2408 & ACCTGCTAACACTGACAGTGC & ACACAGATACCAATGGGTGG & 55 & 189 & 76.58 \\
\hline D3S1300 & AGCTCACATTCTAGTCAGCCT & GCCAATTCCCCAGATG & 56 & $217-241$ & 82.20 \\
\hline D3S1284 & GCCTTGGGGGTAAATACTCT & GGAATTACAGGCCACTGCTC & 58 & 155 & 102.10 \\
\hline D3S1274 & TTATACATCAGTCTCTGGGAAACAC & TACTGTGCATATAGGTTCCTGTGA & 55 & 130 & 107.18 \\
\hline D3S3049 & AAAGACACAAGGGGTTTTAGG & TTGCACATTCCATGAACATC & 52 & 170 & 107.18 \\
\hline D3S1577 & TCAAAAGTTGCATCGC & TCСАТTACAАТССССТG & 50 & 230 & 107.43 \\
\hline D3S2494 & AGTTCCTAACATGTGTCAGGTAAG & CTGGCAGTCTCCAAACATCAGAAC & 56 & $252-253$ & 124.16 \\
\hline D3S2510 & TTGCCACGGATGTAAGGAAGACAATG & TGATTCAGACCCAGTTAACAG & 55 & 500 & 125.00 \\
\hline
\end{tabular}

gradient of FICOLL HISTOPAQUE ${ }^{\circledR} 1077$ (Sigma, USA). Afterwards, the DNA was extracted from the paired samples of tumor and normal tissue with the Wizard $^{\circledR}$ Genomic DNA Purification kit (Promega, USA). The DNA was quantified and diluted to a $50 \mathrm{ng} /$ $\mu l$ concentration.

LOH in $3 p$ was determined using 17 microsatellite markers synthesized by Integrated DNA Technologies, Inc, USA (Table 1) and optimized in previous studies ${ }^{9,10}$. Standard Polymerase Chain Reaction (PCR) was carried out in $25 \mu \mathrm{l}$ final volume containing $50 \mathrm{ng} / \mu \mathrm{l}$ of genomic DNA; 1 X Ammonium buffer; $1.25 \mathrm{mM}$ of $\mathrm{MgCl}_{2} ; 12.5$ pmol of each primer pair; $0.04 \mathrm{mM}$ of each deoxynucleotide (dTTP, dGTP, dCTP, and dATP); 0.5 $\mathrm{U}$ of Taq Recombinant polymerase (Fermentas Life Sciences, USA). Amplification was done on a PT-100 thermocycler(Sensoquest, Germany) with the following thermal profile: initial denaturation at $94^{\circ} \mathrm{C}$ for five min, followed by 35 cycles consisting of denaturation at $94^{\circ} \mathrm{C}$ for $30 \mathrm{~s}$, a specific annealing temperature for each set of primer for $30 \mathrm{~s}$, (Table 1), and an extension at $72^{\circ} \mathrm{C}$ for $1 \mathrm{~min}$; followed by a final extension at $72^{\circ} \mathrm{C}$ for $10 \mathrm{~min}$.

The amplified products were run on $6 \%$ denaturalizing polyacrilamide gels. The gels were preheated at 1700 volts for $30 \mathrm{~min}$. Formamide loading buffer in a 5:1 ratio was added to the PCR products, which were denaturized at $95^{\circ} \mathrm{C}$ for $5 \mathrm{~min}$ and loading into the gel. Electrophoresis was carried out in a vertical chamber (Sequi-Gen, Bio-Rad, USA) during 4-6 hours at constant voltage depending on size of the fragment to accomplish an adequate separation. Then, silver nitrate staining was carried out. Briefly, the gel was washed in $10 \%$ acetic acid for $30 \mathrm{~min}$ with constant agitation, rinsed in $\mathrm{ddH}_{2} \mathrm{O}$ for $2 \mathrm{~min}$; then it was incubated into $1 \%$ nitric acid during $15 \mathrm{~min}$ and again rinsed with $\mathrm{ddH}_{2} \mathrm{O}$. Thereafter, the gel was submerged in a silver nitrate and formaldehyde solution for $30 \mathrm{~min}$ and rinsed with $\mathrm{ddH}_{2} \mathrm{O}$ for $2 \mathrm{~min}$. Then, it was introduced onto a precold developing solution $\left(4^{\circ} \mathrm{C}\right)$ of sodium carbonate, 


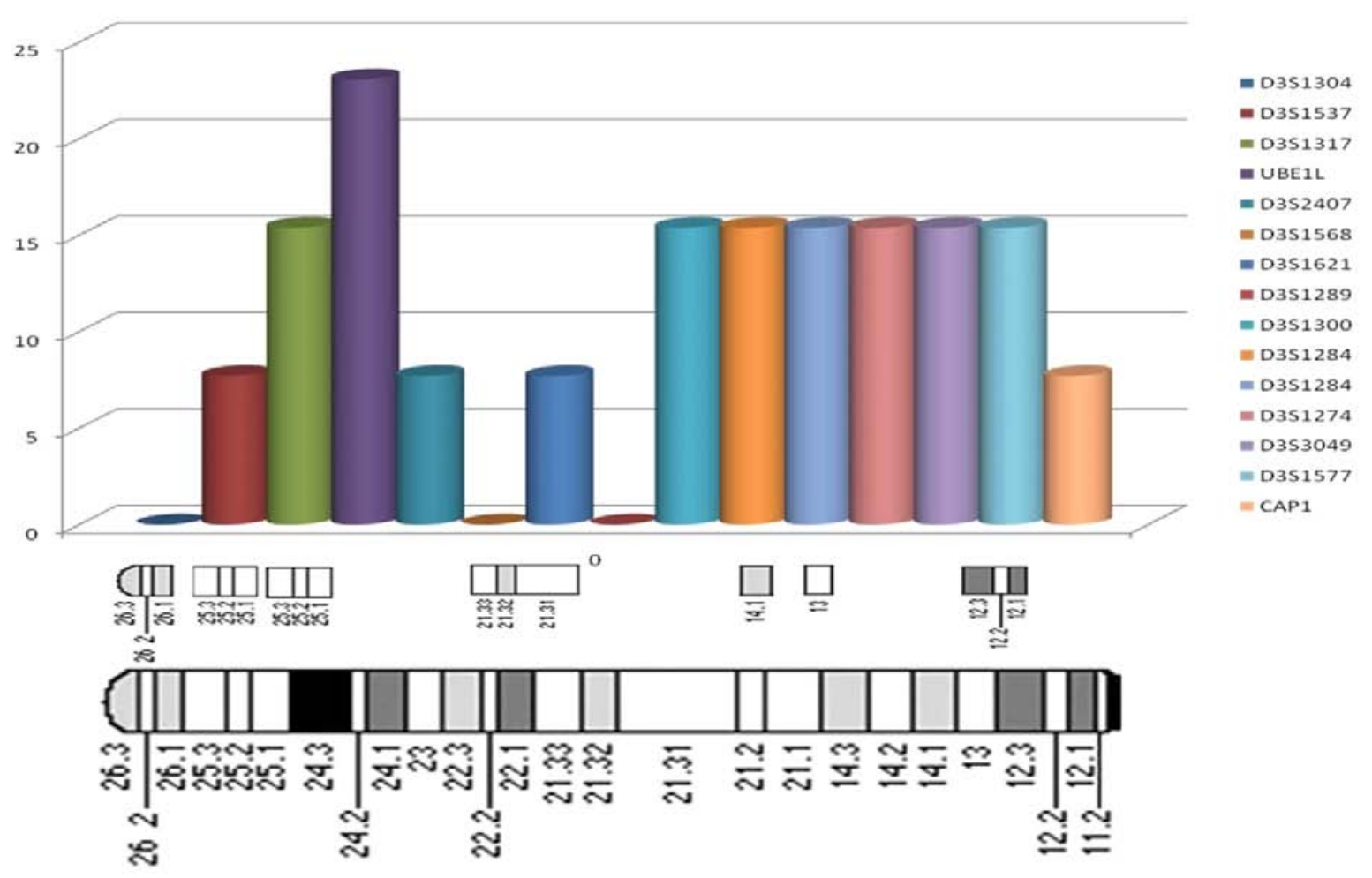

Figure 1. Percentages of LOH for 17 microsatellite markers in 13 samples of human lung cancer

formaldehyde, and sodium thiosulphate until the bands were visualized. Finally, the reaction was stopped with $10 \%$ acetic acid and rinsed with running water. The gel was transferred to Whatman 3MM paper and vacuum dried for $90 \mathrm{~min}$ at $80^{\circ} \mathrm{C}$. $\mathrm{LOH}$ was assigned if an allele was absent or exhibited an altered signal in tumor sample with relationship to normal DNA allelic ratio. A descriptive analysis was conducted for each region studied in chromosome $3 \mathrm{p}$.

\section{RESULTS}

Patient characteristics are described in Table 2. Patients were in an age range between 49 and 78 years, with a mean of 67 years of age. All were active smokers from an early age, with consumption over 20 cigarettes/ day (high consumption). Of these, nine individuals (69.2\%) regularly consumed alcoholic beverages (moderate consumption, between 50 and $100 \mathrm{~g} /$ day). Two samples (15.4\%) were classified as SCLC and ten $(77 \%)$ were classified as NSCLC. NSCLC samples were classified according to the cellular type involved in malignant transformation; six samples were squamous cell carcinoma, two bronchogenic squamous cell carcinomas, one adenocarcinoma, and one squamous cell carcinoma. One of the samples presented non-malignant dysplasia; however, molecular study showed important changes which were considered for analyses.

All tumors were informative for one or more of the markers analyzed. In 11 of 13 samples $(84.6 \%) \mathrm{LOH}$ was found in one or more loci. The markers with major LOH were: UBE1L (23.1\%), D3S1317, D3S1300, D3S1284, D3S1274, D3S3049, and D3S1577 with $15.4 \%$ (Figure 1). LOH percentages for each $3 p$ regions were calculated as: number of $\mathrm{LOH}$ in the region/ number of informative cases in the same region. The percentages obtained were: $17.6 \%$ for $3 \mathrm{p} 24-25,11.6 \%$ for $3 \mathrm{p} 21-22,20 \%$ for $3 \mathrm{p} 13-14$, and $18.4 \%$ for $3 \mathrm{p} 12$ region. In three samples, NT44, NT45, and NT48, microsatellite instability (MSI) and $\mathrm{LOH}$ were simultaneously found (Figures 2 and 3 ). Two squamous cell carcinoma-type NSCLC tumors did not present allelic loss for any loci. One patient, NT55, was found with allelic loss of microsatellite marker D3S1577, flanked by markers CAP1 and D3S3049, both showed allelic retention (Figure 4). 
Table 2

Patients and tumor characteristics

\begin{tabular}{|c|c|c|c|c|c|}
\hline Code & Sex & Age & $\begin{array}{c}\text { Cigarette } \\
\text { consumption }\end{array}$ & $\begin{array}{c}\text { Alcohol } \\
\text { consumption }\end{array}$ & $\begin{array}{c}\text { Histopathological } \\
\text { diagnosis }\end{array}$ \\
\hline NT 43 & $F$ & 60 & High & No & $\begin{array}{l}\text { Non-malignant } \\
\text { dysplasia }\end{array}$ \\
\hline NT 44 & M & 73 & High & Moderate & NSCLC \\
\hline NT 45 & $\mathrm{~F}$ & 49 & High & No & SCLC \\
\hline NT 46 & $M$ & 73 & High & Moderate & NSCLC \\
\hline NT 47 & M & 74 & High & Moderate & NSCLC \\
\hline NT 48 & M & 76 & High & Moderate & NSCLC \\
\hline NT 49 & $\mathrm{~F}$ & 61 & High & No & NSCLC \\
\hline NT 50 & M & 67 & High & Moderate & NSCLC \\
\hline NT 51 & $M$ & 78 & High & No & SCLC \\
\hline NT 52 & M & 64 & High & Moderate & NSCLC \\
\hline NT 53 & $M$ & 70 & High & Moderate & NSCLC \\
\hline NT 54 & M & 68 & High & Moderate & NSCLC \\
\hline NT 55 & M & 62 & High & Moderate & NSCLC \\
\hline
\end{tabular}

F: female; M: Male; NSCLC: non-small-cell lung cancer; $\quad$ SCLC: small-cell lung cancer

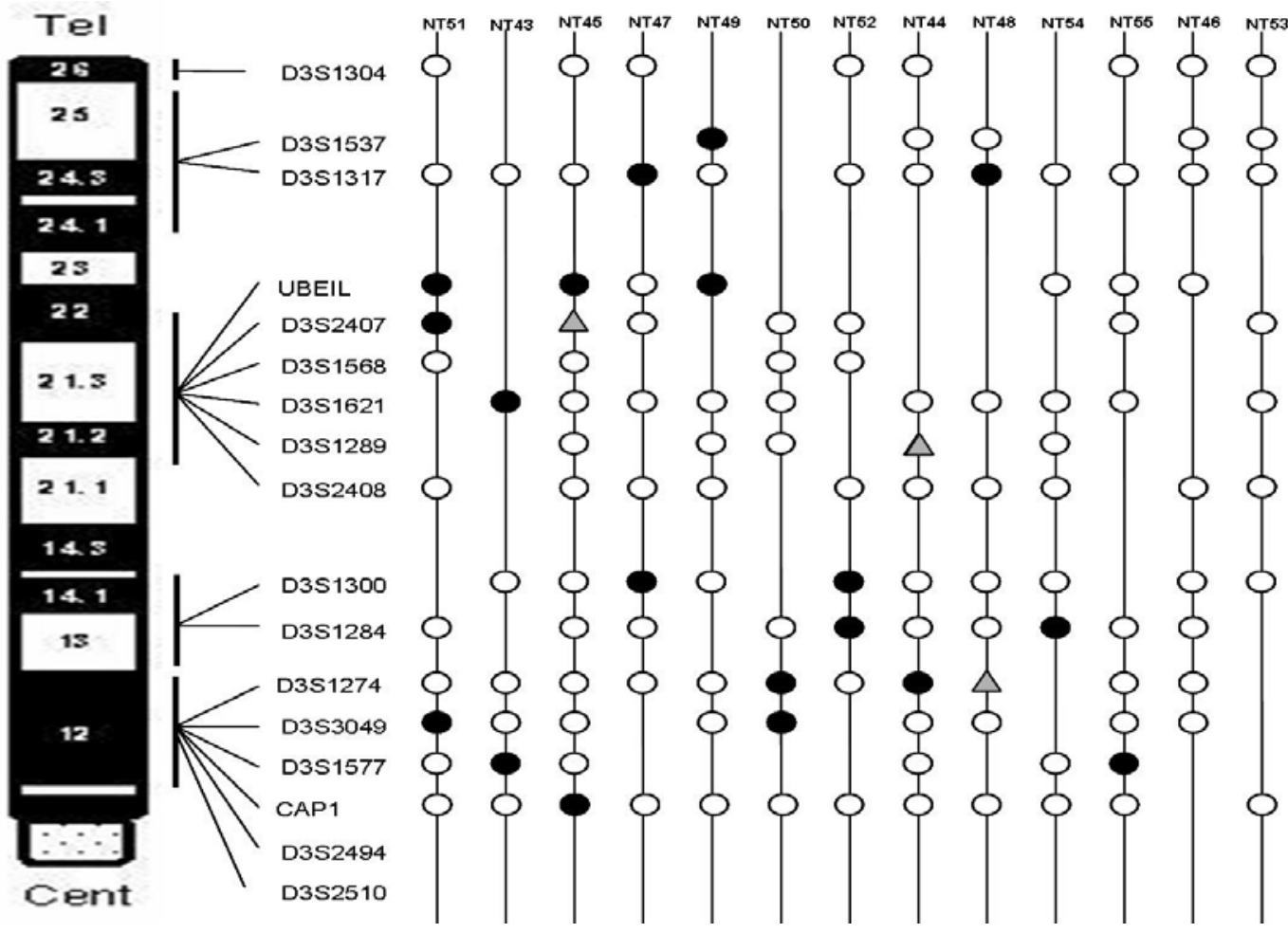

Figure 2. LOH and MSI patterns detected in 13 cases of lung cancer

Loss of heterozygosity; ORetention of heterozygosity; I Not informative; $\boldsymbol{\Delta}$ Microsatellite instability 


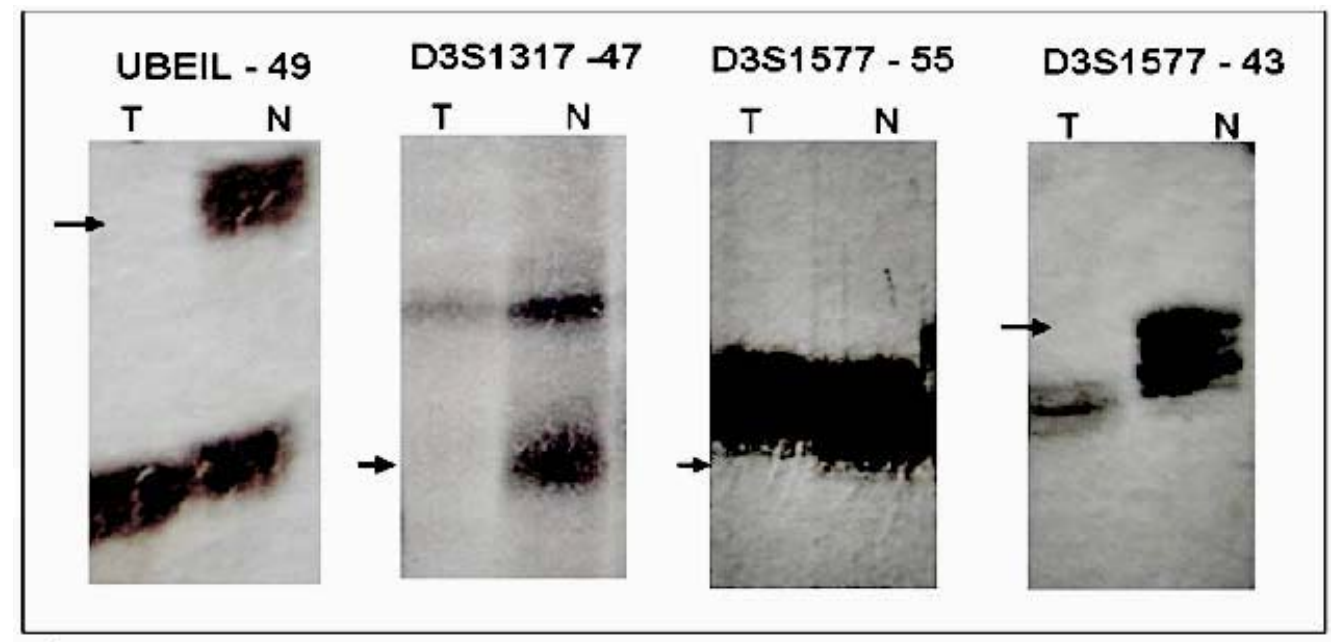

a)

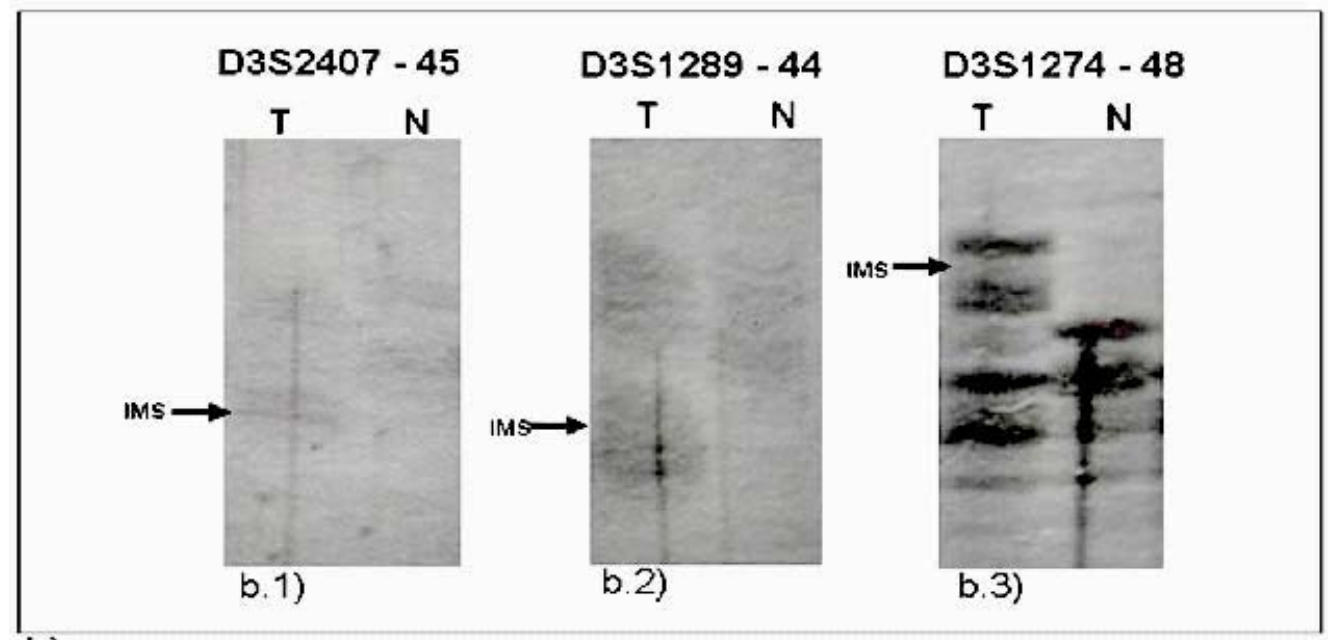

b)

Figure 3. a) Examples of LOH in patients with LC. b) Examples of MSI; b.1) and b.2) located in the $3 p 21-22$ region and b.3) in the 3p12 region. Arrows indicate chromosomal alteration

\section{DISCUSSION}

Tobacco smoking is the main risk factor for developing LC and other types of cancer ${ }^{11,12}$. Furthermore, consumption of alcoholic beverages is also an important factor in lung, mouth, larynx, pharynx, stomach, and liver tumorigenesis when consumption overpasses 100 $\mathrm{g} / \mathrm{day}^{4}$. Patients studied were active smokers for several years (high consumption) and were moderate alcohol drinkers. A meta-analysis performed by Lubin et al. ${ }^{13}$, calculated that $25-68 \%$ of cancers associated to upper aero-digestive tract are related to alcohol consumption and the incidence increases in up to $80 \%$ when is combined with cigarette smoking. The same study reports that the combined effect of alcohol and cigarette smoking increases the risk of developing LC up to 80 times, which indicates the multiplicative effect of both. It is suggesting the first carcinogenic event is caused by tobacco and gives the affected cell a selective advantage that together with alcohol consumption favors accumulation of new cell mutations and alterations that in the end would manifest as a tumor phenotype.

In the 3p24-25 region, three LOH (18.8\%) were found of the total found in 13 patients. Previous reports 


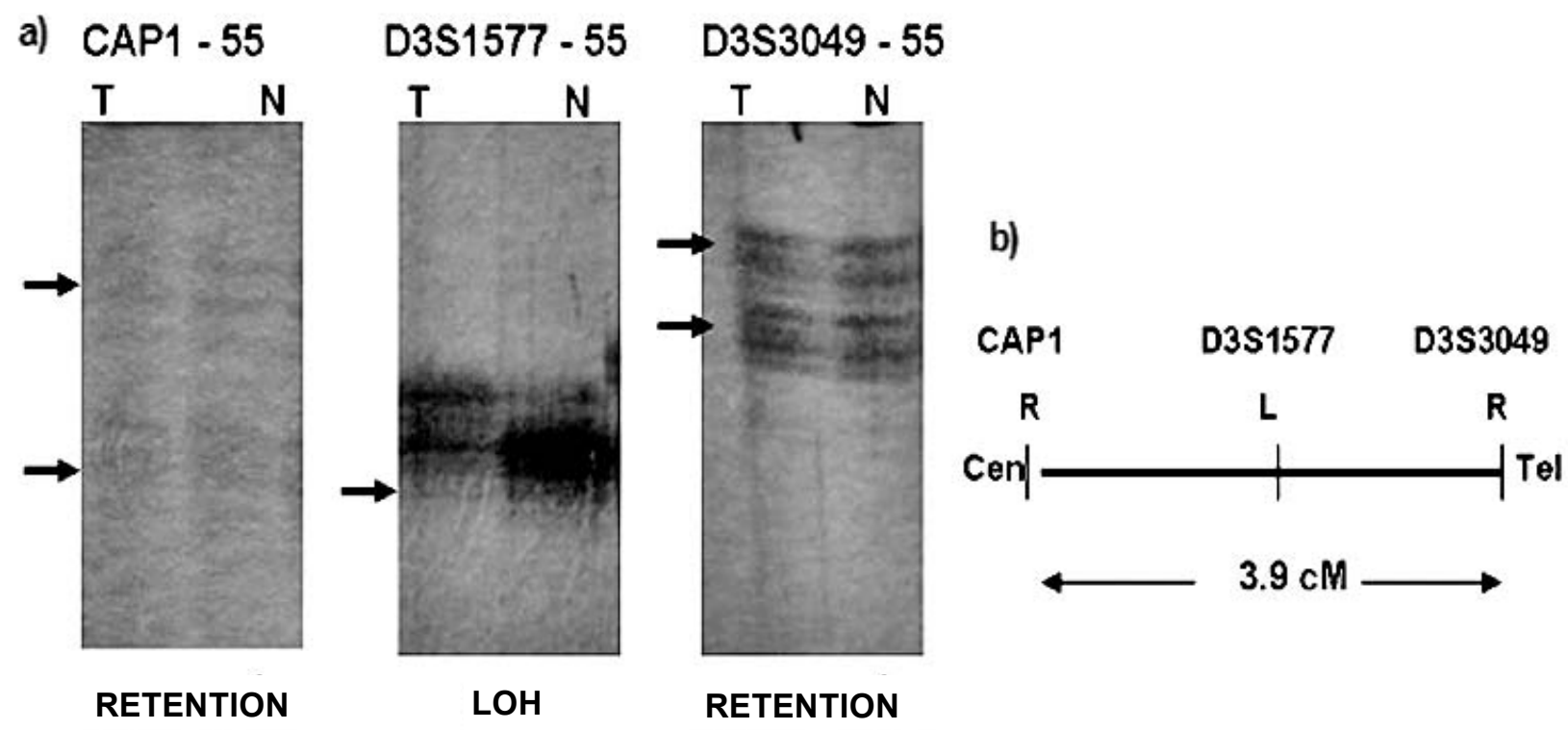

Figure 4. Case NT55. a) The central image shows LOH in the D3S1577 marker, flanked by the microsatellite markers CAP1 and D3S3049, which present retention. b) Schematic representation of the location of the microsatellite markers and the distance in $\mathrm{cM}$

located and identified some genes related to tumor development as $V H L, V H I$, and $R A R \beta$, which are flanked by microsatellites D3S1537 and D3S1317. Miyakis et al. ${ }^{14}$, demonstrated that mutations and $\mathrm{LOH}$ in $\mathrm{VHL}$ gene are not common events in NSCLC; nevertheless, they found $\mathrm{LOH}$ in regions adjacent to this gene in squamous cell carcinoma and adenocarcinomas at $74.6 \%$ and $49.3 \%$, respectively. It is postulated that other still not identified genes located in this region would be genetically altered and involved in tumorigenesis. Our results are agree with the high frequency of LOH in this region; although, it is not comparable with previous study probably due to the low number of microsatellites employed to cover this $4.5 \mathrm{cM}$ region.

For the 3p21-22 region, we used six microsatellite markers covering a distance of $16.58 \mathrm{cM}$, where five LOH $(11.7 \%)$ were found. This region contains the Lung Cancer Tumor Suppressor Gene Region 1 (LCTSGR1), where genes as RASSF1A, HYAL2/LUCA, FUS1/TUSC2, 101F6/CYB561D2, and CPR2L/CPRL2/ TUSC4, are located. Previous studies reporting RASSF $1 A$ gene presents $\mathrm{LOH}$ in up to $75 \%$ of NSCLC ${ }^{15}$. Other authors reported that HYAL2/LUCA, FUS1/ TUSC2, 101F6/CYB561D2, and CPR2L/CPRL2/ TUSC4 genes presented genetic changes ( $\mathrm{LOH}$, point mutations, deletions, and epigenetic changes in different types of cancers and tumor-cell lines); however, they did not identify LOH in LC biopsies ${ }^{5,16}$. The results herein reported show a high frequency of $\mathrm{LOH}$; even though, we cannot guarantee that it corresponds to RASSF $1 A$ gene or to another gene located in this region, which will be the next step to study in our samples.

In 3p13-14 region with a distance of $19.9 \mathrm{cM}$ between markers D3S1300 and D3S1284, four cases of LOH $(20 \%)$ were identified. The most fragile site of the genome is located in this region and the FHIT gene is located here, which is involved in development of different types of cancer. Zabarosky et al. ${ }^{17}$, refer to some studies demonstrated that up to $50 \%$ of LC cases present $\mathrm{LOH}$ in FHIT gene. They also reported that another gene located in this region, FOXP1, presents loss of expression in $51 \%$ of cancers analyzed; however, they did not report LOH in LC samples. Our results are similar to those reported for this region. 3p12 region, contains the Lung Cancer Tumor Suppressor Gene Region 2(LCTSGR2), where the DUTT1 gene is located; to analyze this region, we used five markers covering a 17.82-cM distance and found the greatest number of LOH, $7(18.5 \%)$ for this study. Dallol et al. ${ }^{18}$, demonstrated that hypermethylation occurs in DUTT1 gene in up to $4 \%$ of LCs and observed $\mathrm{LOH}$ for some markers in $3 p 12$ region. Our results show a smaller 
difference than that reported in similar studies ${ }^{19}$. For this region, patients NT43, NT51, and NT55 showed LOH in a microsatellite marker flanked by two markers that showed retention. It suggesting this region is very important in the development of tumorigenesis and there could be a yet unidentified candidate TSG (Figure 2).

There were three cases of microsatellite instability (MSI) in markers D3S2407, D3S1289, and D3S1274 (Figure 2). MSI are changes in the length of the microsatellite marker by insertions or deletions of repetitions in tumor tissue when compared with normal tissue; these alterations may occur due to defects in the DNA repair system (Mismatch Repair-MMR). Nevertheless, others studies identified microsatellite alterations like LOH and MSI in $80.5 \%$ of LC samples for chromosomes 3p, 5q, 8p, 9p, 9q, and 17q. Additionally, studies reporting genes involved in DNA repair do not present changes in their expression pattern in SCLC cellular lines and that MSI is a bio-marker for early detection of LC, mainly in NSCLC ${ }^{20}$.

In conclusion, chromosomal regions were found with high frequency of LOH where TSG involved in LC development are probably located. This work will permit conducting another study in which the number of samples is increased and comparing to a control group with similar characteristics as the cases, together with increasing the number of informative microsatellite markers for the Colombian population to narrow a minimal region to a few hundred base pairs to permitidentifying some yet unknown gene important in lung carcinogenesis, because it was determined that $\mathrm{LOH}$ phenomenon is a critical and early genetic event for onset and development of the disease. Detecting $\mathrm{LOH}$ in tissues of normal appearance surrounding tumor tissue or in tissues with early stages of the disease will lead to early diagnosis and to efficient preventive and curative treatment. Finally, it must be stressed that this is a pioneering study on $\mathrm{LOH}$ conducted in a Colombian population.

Conflict of interest. None of the authors has conflicts of interest related to this study.

\section{REFERENCES}

1. World Health Organization. The global burden of disease: 2004 update. Geneva: WHO Press; 2008.
2. Piñeros M, Ferlay J, Murillo R. Cancer incidence estimates at the national and district levels in Colombia. Salud Publica Mex. 2006; 48: 455-65.

3. World Health Organization. Global health risks. Mortality and burden of disease attributable to selected major risks. Geneva: WHO Press; 2009.

4. Poschl G. Seitz H. Alcohol and cancer. Alcohol Alcohol. 2004; 39: 155-65.

5. Hesson LB, Cooper WN, Latif F. Evaluation of the $3 p 21.3$ tumour-suppressor gene cluster. Oncogene. 2007; 26: 7283301.

6. Kuroki T, Tajima Y, Furui J, Kanematsu T. Common fragile genes and digestive tract cancers. Surg Today. 2006; 36: 1-5.

7. Ogiwara H, Kohno T, Nakanishi H, Nagayama K, Sato M, Yokota J. Unbalanced translocation, a major chromosome alteration causing loss of heterozygosity in human lung cancer. Oncogene. 2008; 27: 4788-97.

8. Breuer RH, Postmus PE, Smit EF. Molecular pathology of non-small-cell lung cancer. Respiration. 2005; 72: 313-30.

9. Martinez A, Walker RA, Shaw JA, Dearing SJ, Maher ER, Latif F. Chromosome 3p allele loss in early invasive breast cancer: detailed mapping and association with clinicopathological features. Mol Pathol. 2001; 54: 300-6.

10. Martínez A. Mapping, identification and characterization of candidate tumour suppressor gene(s) on the short arm of human chromosome 3 involved in several cancers. [ $\mathrm{PhD}$ Thesis]. Birmingham: University of Birmingham Press, University of Birmingham; 2001.

11. Tse LA, Mang OW, Yu IT, Wu F, Au JS, Law SC. Cigarette smoking and changing trends of lung cancer incidence by histological subtype among Chinese male population. Lung Cancer. 2009. 66: 22-7.

12. Sasco AJ. Cancer and globalization. Biomed Pharmacother. 2008; 62: 110-21.

13. Lubin JH, Purdue M, Kelsey K, Zhang ZF, Winn D, Wei Q, et al. Total exposure and exposure rate effects for alcohol and smoking and risk of head and neck cancer: a pooled analysis of case-control studies. Am J Epidemiol. 2009; 170: 937-47.

14. Miyakis S, Liloglou T, Kearney S, Xinarianos G, Spandidos DA, Field JK. Absence of mutations in the VHL gene but frequent loss of heterozygosity at 3 p25-26 in non-small cell lung carcinomas. Lung Cancer. 2003; 39: 273-77.

15. Lerman MI, Minna JD for The international lung cancer chromosome 3p21.3 tumour suppressor genes consortium. The 630-kb lung cancer homozygous deletion region on human chromosome $3 \mathrm{p} 21.3$ : Identification and evaluation of the resident candidate tumor suppressor genes1. Cancer Res. 2000; 60: 6116-33.

16. Sharp TV, Al-Attar A, Foxler DE, Ding L, de A Vallim TQ, Zhang Y, et al. The chromosome 3p21. 3-encoded gene, LIMD1, is a critical tumor suppressor involved in human lung cancer development. Proc Natl Aca Sci. 2008; 105: 19932-37.

17. Zabarovsky ER, Lerman MI, Minna JD. Tumor suppressor genes on chromosome $3 \mathrm{p}$ involved in the pathogenesis of lung and other cancers. Oncogene. 2002; 21: 6915-35.

18. Dallol A, Forgacs E, Martínez A, Sekido Y, Walker R, Kishida $\mathrm{T}$, et al. Tumour specific promoter region methylation of the 


\section{Colombia Médica}

human homologue of the Drosophila Roundabout gene DUTT1 (ROBO1) in human cancers. Oncogene. 2002; 21: 3020-28.

19. Agathanggelou A, Honorio S, Macartney DP, Martínez A, Dallol A, Rader J, et al. Methylation associated inactivation of
Vol. $41 \mathrm{~N}^{\circ} 4,2010$ (Octubre-Diciembre)

RASSF1A from region $3 \mathrm{p} 21.3$ in lung, breast and ovarian tumours. Oncogene. 2001; 20: 1509-18.

20. Hansen LT, Thykjaer T, Ørntoft TF, Rasmussen LJ, Keller P, Spang-Thomsen $\mathrm{M}$, et al. The role of mismatch repair in small-cell lung cancer cells. Eur J Cancer. 2003; 39: 1456-67. 